\title{
Mainstreaming Adaptation Climate Change into Strategic Environmental Assesment Case Study Banyuasin District, South Sumatra Province
}

\author{
Yunan Hamdani ${ }^{1}$, Dwi Setyawan ${ }^{1}$, Budhi Setiawan ${ }^{1} \&$ Azhar K Affandi ${ }^{1}$ \\ ${ }^{1}$ Post Graduate Program of Environmental Science, Sriwijaya University, South Sumatra, Indonesia \\ Correspondence: Yunan Hamdani, Post Graduate Program of Environmental Science, Sriwijaya University, \\ Padang Selasa strait No, 524 Bukit Besar Palembang, South Sumatra, Indonesia. Tel: 62-812-7100-938. E-mail: \\ yunanhamdani@ymail.com
}

Received: September 16, $2014 \quad$ Accepted: October 10, 2014 Online Published: October 27, 2014

doi:10.5539/jsd.v7n6p8

URL: http://dx.doi.org/10.5539/jsd.v7n6p8

\begin{abstract}
South Sumatra Province is one of the areas in Indonesia which tipped to be prone to the impact of climate change and very vulnerable due to its low-land areas that it may threat coastal, water, agriculture, and health sectors of the province. In Banyuasin District, the current program has been planned deep sea port development in Tanjung Api-api area. Coastal flood hazard components caused by a combination of sea level rise, storms, and La-Nina phenomena on maximum tide. In this study measured tidal hazards due to sea level rise. Risk area generated by layering hazard and vulnerability maps using GIS methods. The results of the risk assessment shows increase risk in the water availability at high risk level with percentage area $38.87 \%$ and $46.02 \%$ at baseline conditions and projections. Adaptation efforts conducted to overcome the conditions mentioned above is by controlling the arrangement, the addition of retention ponds as a water storage and flood prevention efforts and also maintaining an area of green open space area above $30 \%$. One of the priorities recommended program is a program of development and the development of sanitation where mitigation / adaptation recommended by increasing the efficiency of use of raw water, saving water resource utilization, and environmental sanitation. The results of this study need to be integrated / mainstreamed into development policies and plans regional / local so helpful to the development of a better way to identify the agenda on national plans, provincial and local levels are associated with adaptation to climate change.
\end{abstract}

Keyword: adaptation, climate change, environment

\section{Introduction}

Climate change causes the change in rainfall patterns, rising temperatures, sea level rise, and extreme climate events that may affect development policies at the macro scale, meso and micro. According to the Intergovernmental Panel on Climate Change (IPCC) in 2007, 1970 through 2004, in Indonesia, there has been a rise in the average annual temperature between $0.2-10{ }^{\circ} \mathrm{C}$ which can cause damage to coastal flooding and storms, the availability of water in the subpolar regions and the tropics wet predicted to increase $10-40 \%$. In dry subtropical and tropical regions, the water is reduced by $10-30 \%$ in the drought areas continues to increase. Rising sea levels also affect the increase in the extent of the areas affected by flood risk. High risk in densely populated lowlands with low adaptive capacity. The impact of sea level rise on average in Indonesia between 0:09 - 0.88 meters by the year 2100 . Floods and storms resulting in $70 \%$ of the total disaster and the remaining $30 \%$ due to drought, landslides, forest fires, heat waves, and others. In Indonesia, the 2003-2005 period, there were 1,429 of disasters. $53.3 \%$ is related to hydro-meteorological disasters (Bappenas and Bakornas PB, 2006). The flood disaster reached (34\%), landslides (16\%). Global warming will cause greater risks of climate catastrophic (Trenberth \& Houghton, 1996; IPCC, 2007; Indonesia Country Report, 2007). The impact of climate change on a system of human life on the water sector is determined by the level of vulnerability of systems to climate change. The degree of vulnerability of the system is determined by three main factors that is the level of exposure, sensitivity and adaptive capabilities. Development and implementation of adaptation without considering the climate change will impact on the system, the level of vulnerability, one form of adaptation activities. In this condition the impact of climate change on the system will be greater. If the adaptive measures are not carried out, Indonesia has the potential to have a shortage of water resources, agricultural output falling, 
and also the loss or destruction of habitat in every ecosystem including coastal areas. Bappenas collaboration with Deutsche Gesellschaftfuer Technische Zusammenarbeit (GTZ) conducted a vulnerability assessment of climate change impacts in national scale (macro) produce a combined report Indonesia Climate Change Sectoral Roadmap (ICCSR). Macro-scale vulnerability assessment continued into the meso-scale (regional / provincial) by DjokoSuroso et al. (2009) in Lombok, West Nusa Tenggara and in Sumatra, South Sumatra Province in particular.

South Sumatra Province suffered exposure to climate change triggered by global warming. The province is broad enough which covers $1^{\circ}{ }^{\prime}-4^{\circ}$ latitude and $102^{\circ}-106^{\circ}$ BT. The area of the province is about $91774.99 \mathrm{~km} 2,30 \%$ are lowland areas that are exposed to climate change (document KRAPI, 2012). Exposure occurs through the medium of the atmosphere and ocean (Bangka Strait), the scientific basis of the study results concluded oceanographic sea level rise to around $13.5 \pm 6.15 \mathrm{~cm}$ in the year (a scenario of greenhouse gas emissions is moderate - SRESa1b). Dangers of coastal inundation due to sea level rise globally, the maximum high tide and extreme climate, including Banyuasin district and Ogan Komering Ilir. Average maximum tide height is about $140 \mathrm{~cm}$ above the average sea level may occur periodically with a probability of $4.7 \%$ per year, while the La-Nina extreme climates with a maximum of $15 \mathrm{~cm}$ may occur once in 1-3 years, and the wave storm (surge) of the South China Sea at a height of about $20 \mathrm{~cm}$ can occur 3 times a year (document KRAPI, 2012).The result from KRAPI South Sumatra reports in 2012, the availability of water in the forecast period showed relatively unchanged and increased if compared to the baseline period of 1970-2000. However, there are indications of hazard reduction in water availability in some areas, in the period of 2010 Musi Rawas and Lubuk Linggau with decreasing value of total run off - $500 \mathrm{~mm} /$ year in the period 2030 and the lowest decline of the region, Musi Rawas and Banyuasin with a value of $-100 \mathrm{~mm} /$ year. Micro-scale vulnerability assessment of climate change impacts related to water availability in particular has not been found so it is necessary to conduct the study. Adaptation strategies that are based on the spatial concept of macro and micro should be viewed as a whole, related to the spatial complexity that faced in each of these scales. As a highly vulnerable country, Indonesia should immediately calculate and incorporate aspects of climate change into national development planning. It takes a comprehensive data related to climate change. The preparation of vulnerability maps consist of various data information on potential impacts of climate change. Vulnerability maps explain the phenomenon, the impact of climate change in the study area spatially. Social-economic data and the environment can be used as an indicator to measure the level of vulnerability (KLH, 2012). Social-economic conditions and the environment may change due to development activities or adaptation efforts. In Banyuasin district, especially in Banyuasin Valley, they built deep sea port located in the area of Tanjung Api-api. The port as a substitute sea port at Musi River in Palembang, which is inadequate for the growth of future activities. Tanjung Api-api port is a potential strategic area for ocean port area and various supporting facilities, may attract and generate growth in various sectors of development in Banyuasin district itself. The effort to make Tanjung Api-api port as the main door of the flow of commodities exports and imports for the southern region will provide significant influence and impact on Banyuasin district. At the macro level study in Banyuasin Valley region located in the lowland areas potentially experiencing the danger of flooding and submergence (Abdurrahman \& Setiawan, 2010). This macro-scale hazard assessment needs to be studied further in the micro scale, to provide more detailed information about the vulnerability climate change in Banyuasin Valley. The result from this study can be described as a micro with a map so it can be predicted which areas that have a low susceptibility to the high about climate change. With the diversity of natural resource conditions and the welfare of society become vulnerable and at risk to climate change. Therefore, it is important to get information about the impact of climate change on the water sector in Banyuasin Valley, among others, how much danger occurred, vulnerabilities and risks faced by current water sector and forward projections. The answer to these problems is useful for the identification of preferred direction adaptation strategies of climate change in water availability sectors and align with the Strategic Environmental Assessment has been prepared by the Banyuasin Goverment. So that, in this study we conducted hazard analysis and vulnerability and also the risk from climate change on the water sector.

\section{Method}

\subsection{Risk Mapping}

Starting from reviewing the hazard and vulnerability to water availability in the region continued research on risk assessment on water availability in Banyuasin Valley region. This study uses the general framework of risk assessment, that is the integration of hazard, vulnerability, and risk in a particular relationship which interrelated and influence each other. Climate change risks $(\mathrm{R})$ is formulated as an overlaid or enlargement of hazard climate change (Hazards; H) and vulnerability to the hazard (Vulnerability, V). The hazard in this study is the result of a hazard scenario component from the sea. Flood hazards models using administrative map of Banyuasin Valley 
region, digital elevation models and land use maps. Vulnerability in this study was obtained from the component parameters of vulnerability which consists of the topography, the level of water use, population density, and social welfare will be overlaid by land use maps. The level of risk is classified into 5 classes: very low risk, low risk, medium risk, high risk and very high risk. The level of risk resulting from the overlay level of hazard and vulnerability levels in two table dimensions. Modeling results were processed using a GIS-based program that is a program ILWIS 3.6 (Integrated Land and Water Information System) which will be used in data processing to obtain hazard maps, vulnerability map and risk maps in the study locations. The method in this study uses a micro-level approach. Geographic Information Systems are used in the assessment of risk analysis as shown in Figure 1.

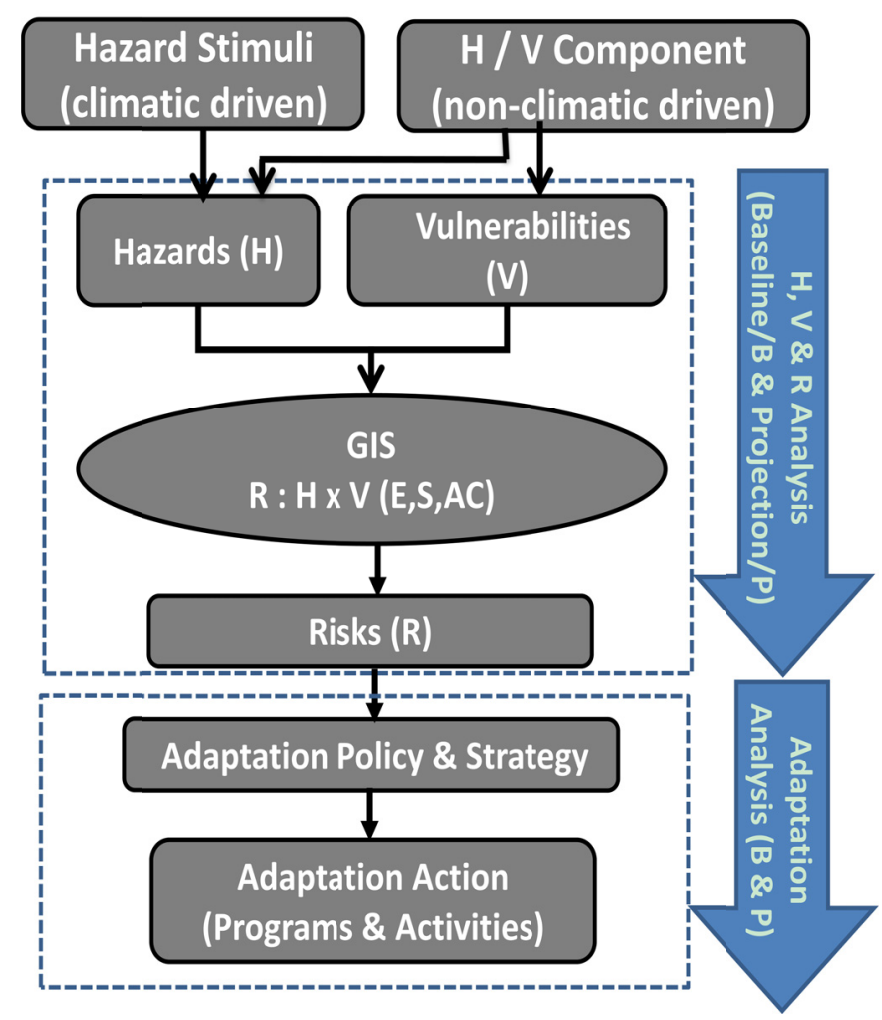

Figure1. The main framework in the risk assessment of climate change (Abdurahman and Setiawan, 2010)

\subsection{Adaptation Action Plan}

Adaptation and vulnerability assessment, where risk assessment is one approach that will be applied in mainstreaming adaptation options in regional policymaking. Adaptation action plan that is required to face the risks that occur on water availability, based on the results obtained and issues relating to the spatial pattern Banyuasin Valley area, then make a conclusion of the study, recommendations and suggestions needed. Adaptation to climate change is simply defined as efforts to reduce the damage or to increase the chances of climate change that linked to the Strategic Environmental Assessment (SEA) for the water sector. Types of adaptation in this case more inclined to adaptation driven by policy (policy-driven adaptation). In this study also involves two levels of adaptation, that is: 1) strengthening the capacity of information providing about vulnerabilities and risks due to climate change; and 2) the implementation of adaptation actions that include vulnerability reduction measures or risks to the availability of raw water due to climate change impacts.

\section{Results}

\subsection{Risk Assessment}

The results of overlay hazard modeling and risk maps obtained vulnerabilities. Knowledge about the hazard and vulnerability becomes a very important material to determine the level of risk to climate change at this time and the projection in 2030 faced by people living in the districts who are spread throughout Banyuasin Valley Region. Once the spatial distribution from the degree of hazard, vulnerability, and risk known to the region will be formulated various strategies of adaptation to climate change impacts and targeted appropriately. In the baseline 
condition, in Banyuasin Valley and the surrounding areas there are areas that have a very low risk. The low risk area is 6942 ha $(25.37 \%)$, moderate risk is 7318 ha $(26.74 \%)$, high risk is 10632.5 ha $(38.87 \%)$ and very high risk is $2469.5 \mathrm{ha}(9.02 \%)$. There is an increase the percentage of riskthat moderaterisk at $26.74 \%$ to $39.25 \%$ and highrisk levels at $38.87 \%$ to $46.02 \%$ for baseline condition and projection condition in Banyuasin Valley. The high risk area is located on Banyuasin II district from three district at Banyuasin Valley Region. Results of risk modeling in baseline conditions (2010) and projected (2030) can be seen in the figure 2.

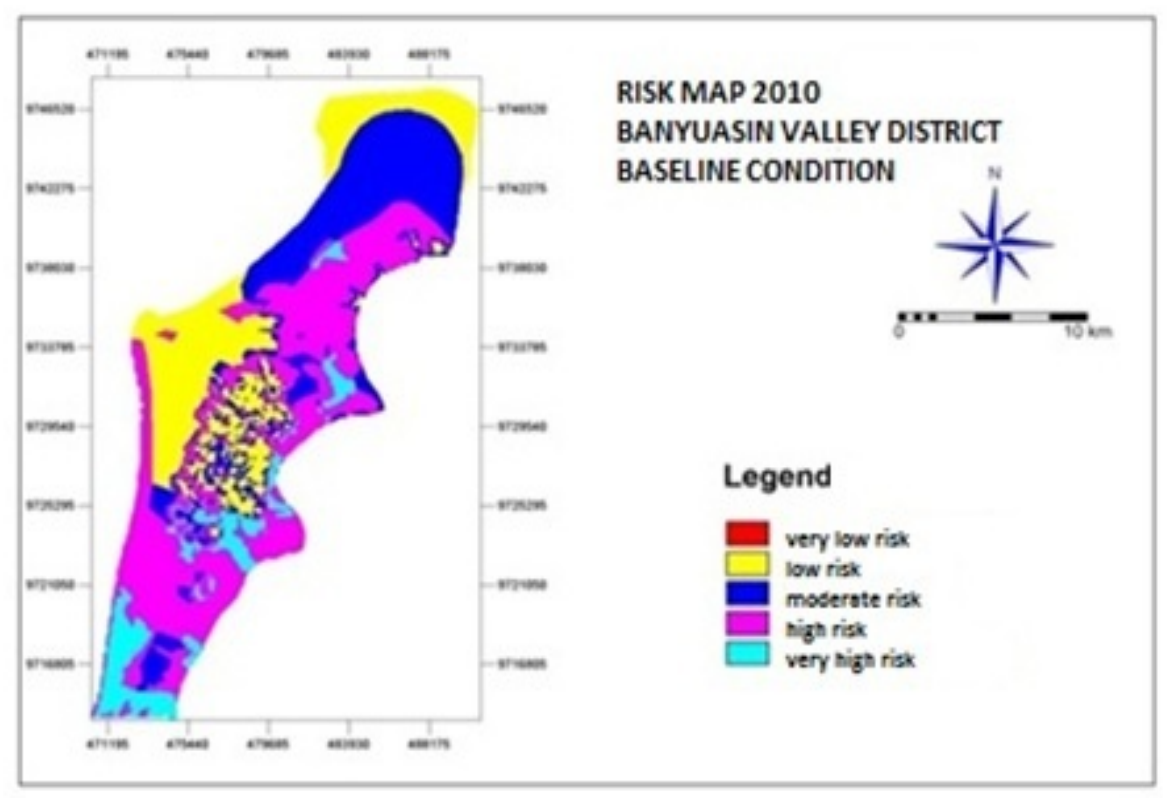

(a)

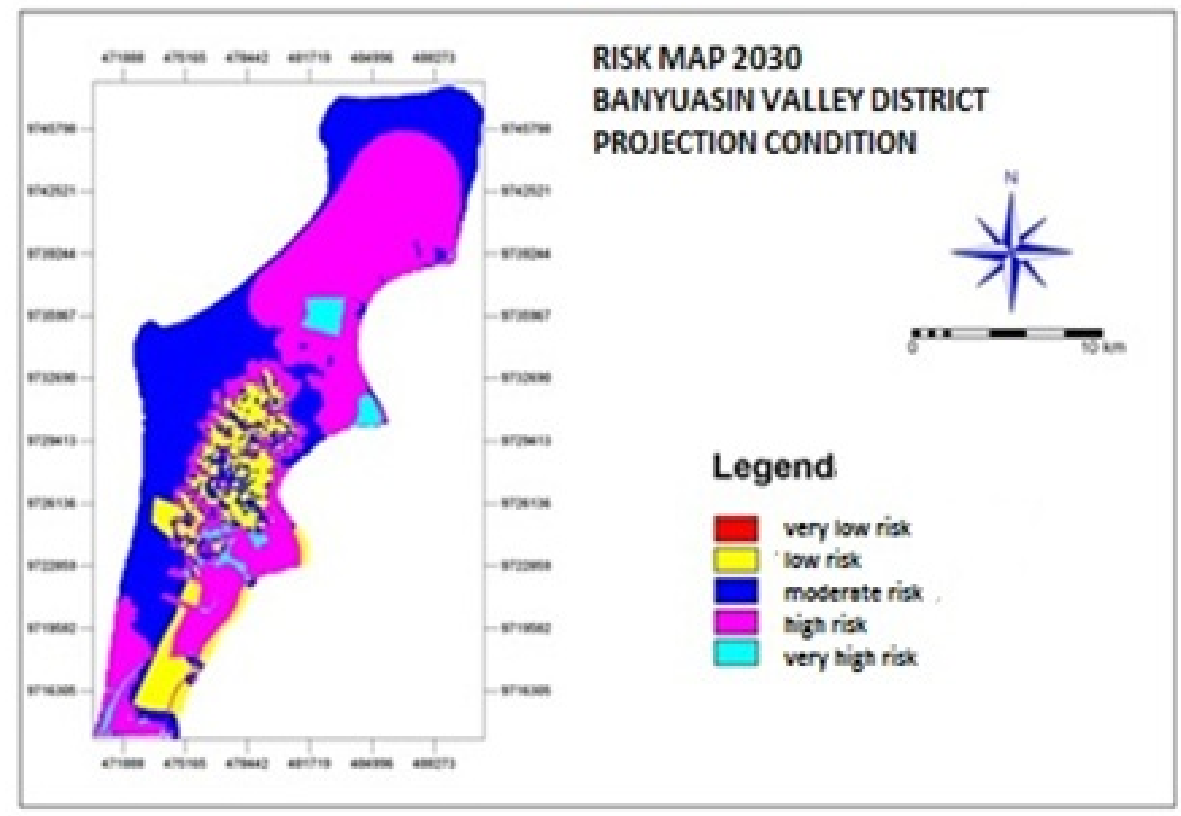

(b)

Figure 2. Risk map water availability in Banyuasin Valley region at 2010 (a) and 2030 (b) 
Table 1. Extensive risk areas at Banyuasin Valley

\begin{tabular}{lllll}
\hline \multirow{2}{*}{ Risk Level } & \multicolumn{2}{l}{ Baseline Condition (2010) } & \multicolumn{2}{l}{ Projection Condition (2030) } \\
\cline { 2 - 5 } & Area (ha) & Percentage (\%) & Area (ha) & Percentage (\%) \\
\hline Very Low Risk & 0 & 0 & 2.25 & 0.01 \\
Low Risk & 6942 & 25.37 & 3176.25 & 11.51 \\
Moderate Risk & 7318 & 26.74 & 10833.25 & 39.25 \\
High Risk & 10636.25 & 38.87 & 12703.5 & 46.02 \\
Very High Risk & 2469,5 & 9.02 & 887.75 & 3.22 \\
\hline
\end{tabular}

Administratively, in high-risk area and very high area the most extensive is Banyuasin District II and MuaraTelang with each risk area of 5591.5 and 1061.5 ha. In the projection condition, spacious area that has a very low risk amounted $2.25 \mathrm{ha}(0.01 \%)$, low risk is about 3176.25 ha $(11.51 \%)$ moderate risk is about 10833.25 ha $(39.25 \%)$, high risk 12703.5 ha $(46.02 \%)$ and very high risk is about 887.75 ha $(3.22 \%)$. While administratively high-risk areas most widely lies on Banyuasin District II that is 5591.5 ha (baseline) and 9388.75 Ha (projection) as shown in Table. 2.

Table 2. Extensive risk area per subdistrict in Banyuasin Valley region

\begin{tabular}{lccccc}
\hline \multirow{2}{*}{ District } & \multicolumn{5}{c}{ Extensive Risk Area (ha) } \\
\cline { 2 - 6 } & Very Low & Low & Moderate & High & Very High \\
\cline { 2 - 6 } & 0 & 6909.75 & 6577.25 & 5591.5 & 477.5 \\
\hline Banyuasin II & 0 & 32.25 & 737.25 & 2610.5 & 1061.5 \\
MuaraTelang & 0 & 0 & 3.5 & 2434.25 & 930.5 \\
Tanjung Lago & 0 & 1603.5 & 8275.25 & 9388.75 & 523 \\
\hline Banyuasin II & 2.25 & 1571 & 392 & 2216 & 262.5 \\
MuaraTelang & 0 & 1.75 & 2166 & 1098.75 & 102.25 \\
Tanjung Lago & \multicolumn{5}{c}{ Projection condition (2030) } \\
\hline
\end{tabular}

The results of risk analysis above, generally indicates that the area has high risk toward water availability with the Banyuasin II District is the most risky region toward climate change, especially in residential areas and urban. The combination of vulnerability factors such as low soil down towards sea level on average, the slope of the topography, land area converted to residential, industrial, high population highly affects the level of risk to the availability of water that is necessary to the control of spatial planning in order to guarantee more space for water absorption, controlling the population density, increasing the water supply infrastructure (water supply), either in Banyuasin Valley or in cooperation with administrative region that has sufficient water resources, reduce the level of water demand by the deployment of an industrial area and other water users and also to improve the welfare of the population and equitable distribution of population welfare. The result accuracy of the risk analysis highly influence the success rate of implementation of the proposed adaptation strategies into development planning. To anticipate the risk of water shortages in Banyuasin II District the industrial park are required to make water treatment plant not only to meet the needs of industry but also can be used for residential area that support the industrial park, however, most of the management handed over to local authorities so that any resident outside the region can use it and there is no gap between the family area with residents outside the region (old citizens).The existence of recreational facilities is necessary for society to dispel the boredom of daily work. This area is recommended for the presence of recreational facilities related to water, and of course the location is on the edge Telang River near from the town / settlement. This point utilizes riverside part that is risky for industrial investment but it is quite safe for recreation. Special for dense mangrove forest area in northern Sungsang, its utilization directed as an eco-tourist area. Specifically there is also allocated a central park, green zones that accommodate major sports venues and great forest areas, located on the opposite side of the 
road west axis (primary arteries and railway tracks). For sports and recreation in this zone include golf courses the needs complement of industrial areas. While some of these zones intended for forest crops as compensation for pollution produced from the production process (carbon trade-offs). The provision of these areas are to ensure that the industrial output from the planning area have already take into account the environmental aspect of sustainability that will be easier to get a place in the international market. Management of this section can be performed by a company or government. Overall, the green open spaces in industrial areas should not be less than $10 \%$, and for urban areas is $20 \%$. For the amount of planning area is very safe and beyond the minimum limit, which reached about $30 \%$ of the territory.

\subsection{Action Adaptation Options}

Adaptation in general is all efforts to ensure the management of water resources properly based on past experience, as well as forward projections. Implementation considerations are danger, vulnerabilities, and impacts due to climate change, time and exact location. The purpose of the overall adaptation is to obtain the proper performance from the management of water resources to deal with climate change issues. For that, there are two types of adaptation, that are independent adaptation (autonomous), and planned adaptation (planned adaptation or policy driven adaptation). Independent adaptation actually can take place without associated with climate change, as long as there are efforts to change the circumstances and habits for the better water management, such as avoiding a water crisis, drought, and floods. However, those efforts are generally responsive and without being based on the results of studies on the projected state and the water behaviour. Planned adaptation must take into account about climate change carefully. Adaptation measures at the local level is the best observation. Anticipation or real experiences on the impact of climate change establishdecision making and action adaptation - then becomes the translation of science and the capacity in activity and habit. In principle, the risk associated with a decrease in the availability of water, there are two adaptation options which can be applied as reported in the Fourth Assessment Report of Working Group II, IPCC (IPCC, 2008), an adaptation from the supply side, and the adaptation from the requirements or demand (demand side). Each adaptation is consists of several types of activities, The following table are the prospects to be applied in Banyuasin Valley Region.

Table3. Several adaptation options for water supply and needs

\begin{tabular}{ll}
\hline \multicolumn{1}{c}{ Supply Side } & PROSPECT \\
\hline Searches and Groundwater & $\mathrm{XXX}$ \\
Increased water storage capacity by creating retention pond, reservoir, or dam & $\mathrm{XXXX}$ \\
Sea water desalinization & $\mathrm{X}$ \\
Expansion of rainwater reservoir & $\mathrm{XXXX}$ \\
Invasive vegetation displacement (absorb water) from the edge of rivers or lakes & $\mathrm{XX}$ \\
Water Transfer & $\mathrm{XX}$ \\
\hline
\end{tabular}

\begin{tabular}{ll}
\hline \multicolumn{1}{c}{ Demand Side } & PROSPECT \\
\hline $\begin{array}{l}\text { Increased water use efficiency by water recycling } \\
\text { Reduction in water demand for irrigation by changing the cropping calendar, plant mix, irrigation } \\
\text { method and the area of land planted }\end{array}$ & $\mathrm{XXXX}$ \\
$\begin{array}{l}\text { Reduction in water demand for irrigation by importing agricultural products eg virtual water } \\
\text { (virtual water concept) }\end{array}$ & $\mathrm{X}$ \\
$\begin{array}{l}\text { Encouraging the practice of local wisdom for sustainable water use } \\
\begin{array}{l}\text { Expansion of the use of water markets for relocating the water to high-value use } \\
\text { Expansion the use of economic incentives, including the implementation of water meters and } \\
\text { prices to encourage conservation }\end{array}\end{array}$ & $\mathrm{XXX}$ \\
\hline
\end{tabular}

Source: IPCC, 2008 with modification.

Description: The degree of possibility or prospect of execution in the Area: XXXX: high prospect and highly recommended; XXX: prospects and recommended; XX: enough prospect, but not recommended; X: low prospects, not recommended; *): Limited to urban areas. 
Adaptation choice is determined based on the results of the risk assessment, considering the choice of adaptation to climate change is very influential on development planning in Banyuasin Valley and surrounding areas. So that, the proper adaptation for those regions is individual-level / community-level adaptation that will be grouped into two classes, that are adaptation in short time (immediately) and adaptation in long period time to support the development planning. For adaptation to the risk of decreased in water availability, some of the options can be used, so that adaptation steps could be double functions. For example, the expansion of water storage. Moreover, there are other options for adaptation to the risk of decreased in water availability, both upstream aspects such as management of water catchments or watersheds, and downstream aspects such as the construction of embankments and polders. Some adaptation options through risk in water availability are increasing water storage capacity to create a retention pond, or reservoirs, prospecting and retrieval of ground water, reforestation or rehabilitation of water catchment areas, forests or critical land and improvement of protected forest areas. In terms of water demand with increasing water use efficiency by recycling water. In this case needs to be recognized by policy makers or planners of water management that we may not be able to solve all the factors of climate change uncertainty issues and using any possibilities of hydrologic change assessment will provide evaluation choices of response options and better risk. In Banyuasin Valley Region there are two districts that have high and very high risk they are Banyuasin II and MuaraTelang District where the level of risk in that area is a major priority in the determination of adaptation measures. Adaptation choice paired with diverse vulnerability factors in that district such as water demand condition, land area that used for residential, industrial and also dense population so that arranged adaptation options can be adjusted with vulnerability factors such as shown in Table 4.

Table 4. Adaptation choice of water availability in Banyuasin Valley

\begin{tabular}{|c|c|c|}
\hline District & Provision and Water Location Overview & Adaptation Choice \\
\hline Banyuasin II & $\begin{array}{l}\text { - Flanked by Banyuasin river in the west } \\
\text { and east of Telang river and bordered by } \\
\text { Bangka Strait in the North } \\
\text { - The current water demand derived from } \\
\text { water wells, rainwater and river water } \\
\text { - Water demand in projection condition will } \\
\text { increase significantly with the new city } \\
\text { plan for residential, business center and a } \\
\text { variety of industrial }\end{array}$ & $\begin{array}{l}\text { - Development of an artificial water catchment } \\
\text { areas in Telang protected forest } \\
\text { - Rain water harvesting in areas that do not } \\
\text { have potential groundwater } \\
\text { - Development of surface water resources by } \\
\text { the provision of water from PDAM / IPA } \\
\text { procurement } \\
\text { - Desalination of sea water if necessary } \\
\text { - Control of population } \\
\text { - Supervising and controling the spatial } \\
\text { planning }\end{array}$ \\
\hline MuaraTelang & $\begin{array}{l}\text { - Bordered by Telang river in the east } \\
\text { - Water demand is currently derived from } \\
\text { wells, rainwater and river for bathing, } \\
\text { washing and lavatory needs } \\
\text { - Water demand will increase in the } \\
\text { projection conditions with the residential } \\
\text { plan and the basic metals industry }\end{array}$ & $\begin{array}{l}\text { - Development of an artificial water catchment } \\
\text { areas in the protected forest } \\
\text { - Development of surface water resources in } \\
\text { the Sebalik canal by making IPA } \\
\text { - Rain water harvesting in areas that do not } \\
\text { have potential groundwater } \\
\text { - Control of space utilization }\end{array}$ \\
\hline
\end{tabular}

\subsection{Strategic Environmental Assessment on Banyuasin Valley Region}

Law No. 32 of 2009 on the Protection and Environmental Management mandates to the central government and provincial governments are required to make SEA to ensure that the principles of sustainable development has become a basic and integrated development of an area and / or policies, plans and / or programs (hereinafter called PPP). As an effort to ensure sustainability of development in the future in sustainable development planning is to integrate environmental concerns in the direction of the strategic decision-making at the level of policy, plan or program (PPP) through the application of SEA.

Banyuasin district as part of South Sumatra Province have ti integrate every PPP in the corridor for environmentally sustainable development. It is necessary to remember that development programs are not only 
local scale, but also internationally which could impact on all aspects of life (environmental, economic, social and cultural). At this point, the SEA is here to make the PPP be better in everyone eyes who eventually returned to the main objective, the development of people's welfare. Banyuasin District Government through the Environmental Control Working Group make SEA recommendations based on the formulation of mitigation / adaptation, and / or alternative. Those recommendations are the improvements recomendation of vision and mission, goals and objectives, strategies and direction of policy, public policy and medium-term development program area. One of priority programs is development of sanitation where mitigation/adaptation step that recommended are the improvement of water use efficiency, water resources utilization saving, and environmental sanitation. The results of this study need to be integrated / be the priority plan and make regional / local development policies in order to be beneficial towards better development by identifying the national plan, provincial and local levels which associated with climate change adaptation so that stakeholders have basic association of current documents which aims to arrange the recommendation adaptation options that need to be the next annual development plan of the local government. The proposed adaptation strategies in South Sumatra province through the risk of water shortage is by improving services in public water supply (PDAM), utilization of ground water by developing boreholes, rainwater harvesting and conservation of vegetation (Document KRAPI Sumatra, 2012). The central government has developed a National Action Plan - Adaptation to Climate Change (RAN - API) where the programs related to climate change adaptation in the water sector included in living systems related to the issue of climate change as shown in Table 5.National Action Plan Program was followed by its descendants, the Regional Action Plan programs in all districts / cities in Indonesia. At the Regional Action Plan Strategic Plan for Water and Environmental Sanitation Banyuasin District 2014-2018 have entered the program in line with the RAN-API program as shown in Table 6.

Table 5. The matrix of the national action plan on climate change adaptation

\begin{tabular}{|c|c|c|c|c|}
\hline Sector & Action Plan & Indicator / Target & Period & $\begin{array}{c}\text { Target / } \\
\text { Location }\end{array}$ \\
\hline 2 & \begin{tabular}{llr} 
Response & \multicolumn{2}{c}{ infrastructure } \\
provision & to & climate \\
change & in & urban \\
residential areas &
\end{tabular} & $\begin{array}{l}\text { Development and Management of Water } \\
\text { Management System that fulfill the } \\
\text { quality standards }\end{array}$ & $2015-2019$ & National \\
\hline 4 & $\begin{array}{l}\text { Maintenance and } \\
\text { Rehabilitation of water } \\
\text { resources in coastal areas } \\
\text { and small islands }\end{array}$ & $\begin{array}{l}\text { - Implementation of sustainable water } \\
\text { resources management activities, such } \\
\text { as the use of absorption wells, dams, } \\
\text { levees, and drinking water } \\
\text { management by using appropriate } \\
\text { technology } \\
\text { - Implementation of controlling } \\
\text { activities of water resources utilization } \\
\text { in coastal areas and small islands }\end{array}$ & $\begin{array}{l}2015-2019 \\
2020-2024\end{array}$ & $\begin{array}{l}\text { High Risk } \\
\text { Zone }\end{array}$ \\
\hline
\end{tabular}

Source: RAN - API, 2012 Document 
Table 6. Regional action plan program Banyuasin District

\begin{tabular}{|c|c|c|}
\hline $\begin{array}{l}\text { Program } \\
\text { Number }\end{array}$ & Program & Purpose \\
\hline 2 & $\begin{array}{l}\text { Development of Water Supply } \\
\text { System (SPAM) }\end{array}$ & $\begin{array}{l}\text { Each Capital District has the eligible SPAM infrastructure for } \\
\text { Quality, Quantity, Continuity and Affordability }\end{array}$ \\
\hline 4 & Rural water supply development & $\begin{array}{l}\text { Each village has eligible Drinking Water Infrastructure for } \\
\text { Quality, Quantity, Continuity and Affordability }\end{array}$ \\
\hline 7 & $\begin{array}{l}\text { Protection and conservation of } \\
\text { natural resources }\end{array}$ & $\begin{array}{l}\text { Reforestation of raw water sources potential area } \\
\text { - Controlling the catchment area of raw water source }\end{array}$ \\
\hline 8 & Optimizing service of PDAM & $\begin{array}{l}\text { - } 19 \text { District have access to drinking water from PDAM } \\
\text { - Restructuring of drinking water tariff } \\
\text { - Increasing the engineering and management capacity } \\
\text { - Technology development in plumbing system } \\
\text { - Increasing services expansion }\end{array}$ \\
\hline 9 & Decrease the levels of water loss & $\begin{array}{l}\text { - PDAM lowered the leaking until } 30 \% \\
\text { - System formation of service zone } \\
\text { - Establishment of Ready to Drink Water Region }\end{array}$ \\
\hline 20 & $\begin{array}{l}\text { Increasing the role of Facility } \\
\text { Management Agency (BPS) in } \\
\text { protection activities of Raw } \\
\text { Water Sources }\end{array}$ & $\begin{array}{l}\text { - Management of BPS } \\
\text { - Development of BPS as receiver of AMPL facility }\end{array}$ \\
\hline 21 & $\begin{array}{l}\text { Protection and conservation of } \\
\text { forest resources }\end{array}$ & Land rehabilitation, ground and water \\
\hline
\end{tabular}

Source: RAD AMPL Banyuasin District, 2013

Adaptation options are proposed to adjust the development system of Banyuasin District. Currently Banyuasin Government has enacted RTRW and RDTR for Tanjung Api-api region. Based on the identification of spatial development programs that exist in coastal areas, indicating that almost the entire program is integrated with the adaptation concept and can be developed through appropriate adaptation strategies. On the other hand, the identified area that has high risk need to embrace the concept of integrated coastal zone management, for example through structuring / remanagement and coastal protection either through soft structures or hard structures.

\section{Conclusion}

From the analysis result, can be concluded that the results of risk analysis at the site showed that the level of risk in 2030 is $46.02 \%$ at high risk and mostly located in Banyuasin II District. Generally, Banyuasin Valley is relatively safe from climate change impact in baseline condition, while in projected condition it need the spatial arrangement control based on what has been planned. Adaptation strategies from the supply side is the increasing water storage capacity to create a retention pond, or reservoir and expansion of rainwater reservoir, and from necessity side is to increase water use efficiency by recycling water. Recommendations on improvement of the formulation in the form of vision and mission, goals and objectives, strategy and policy, public policy and the medium-term development programs so that stakeholders have a basic the linking of the existing document with the aim to develop recommendations adaptation options that need to be further integrated into the annual development plan of the next local government.The strength of the approach includes primary on a systematic step by stepprocess. However, it has also requires good historical data of climate aspects whichare unfortunately not easily available in Indonesia. Application of risk assessment in the Banyuasin District South Sumatra Province was able to delineate the risk maps. Based on the risk maps then adaptation option was identified.

\section{References}

Abdurahman, O., \& Budhi, S. (2010). Indonesia Climate Change Sectoral Roadmap: Water Resources Sector. Badan Perencanaan Pembangunan Nasional (Bappenas). Indonesia.

Bappeda Kabupaten Banyuasin. (2008). RDTR Kawasan Pendukung Pelabuhan Tanjung Api-api. Indonesia. 
Bappeda Kabupaten Banyuasin. (2013). Draft Rencana Aksi Daerah Rencana Strategis Air Minum dan Penyehatan Lingkungan (RAD Renstra AMPL) Kabupaten Banyuasin Tahun 2014-2018. Indonesia.

Bappeda Kabupaten Banyuasin. (2013). KLHS RPJMD Kabupaten Banyuasin tahun 2014-2018. Indonesia.

Bappeda Provinsi Sumatera Selatan. (2010). RTRW Provinsi Sumatera Selatan 2011-2030. Indonesia.

Brooks, N. (2003). Vulnerability, risk and adaptation: A conceptual framework, Tyndall Center. Working Paper No 38.

Djoko, S., Tri, W. H., Ibnu, S., Hamzah, L., Abdurahman, O., \& Budhi, S. (2009). Vulnerability of Small Islands to Climate Change in Indonesia: A case study of Lombok Island, Province of Nusa Tenggara Barat. Proceeding World Oceanic Conference: Water and Coastal Sector. Manado.

Downing, T. E., \& Patwardhan, A. (2003).Vulnerability Assessment for Climate Adaptation, Adaptation Policy Framework: A Guide for Policies to Facilitate Adaptation to Climate Change. UNDP.

IPCC. (2001). Climate change 2001: Impacts, Adaptation and Vulnerability, Summary for Policymakers. WMO.

IPCC. (2007). Climate Change 2007: The Project Science Basis. Contribution of Working Group I to the Fourth Assessment Report of the Intergovernmental Panel on Climate Change.

ISDR. (2004). Living With Risk. United Nation, Washington.

Kementerian Negara Lingkungan Hidup. (2009). Buku Panduan Kajian Kerentanan dan Dampak Perubahan Iklim: Untuk Pemerintah Daerah. Indonesia.

Kementerian Negara Lingkungan Hidup. (2012). Kajian Resiko dan Adaptasi Perubahan Iklim Sumatera Selatan (KRAPI): Laporan Final. Indonesia.

Kementerian Negara Lingkungan Hidup. (2012). Kajian Resiko dan Adaptasi Perubahan Iklim: Kota Tarakan. Sumatera Selatan, dan Malang Raya, Ringkasan untuk Pembuat Kebijakan. Indonesia.

Kementerian Perencanaan Pembangunan Nasional / Badan Perencanaan Pembangunan Nasional (Bappenas), (2014). Rencana Aksi Nasional Adaptasi Perubahan Iklim (RAN - API). Indonesia.

Messner, F., \& Meyer, V. (2005), Flood Damage, Vulnerability and Risk Perception - Challenges for flood Damage Research. UFZ Discussion Paper 13/2005.

OECD. (2009). Integrating Climate Change Adaptation into Development Co-operation: Policy Guidance, Chapter 10: Introduction to Local Level.

Peterson, L., \& Haug, G. (2005). Climate and the Collapse of Maya civilization.

Rygel, L., O'sullivan, D., \& Yarnal, B. (2006). A Method for Constructing a Social Vulnerability Index: An Application to Hurricane Storm Surges in a Developed Country, Mitigation and Adaptation Strategies for Global Change. http://dx.doi.org/10.1007/s11027-006-0265-6

Sadler, B. (2005). Strategic Environmental Assessment at the Policy Level Recent Progress, Current Status and Future Prospects.Praha.

Stéphane, H., \& Jan, C. M. (2011). Understanding Climate Change Impacts, Vulnerability and Adaptation at City scale: An introduction Climatic Change.

Trenberth et al. (1996). Technical summary of Climate Change 1995. In J. T. Houghton, L. G. MeiraFilho, B. Callander, N. Harris, A. Kattenberg, \& K. Maskell (Eds.), The science of Climate Change. Contribution of WG 1 to the Second Assessment Report of the Intergovernmental Panel on Climate Change (pp. 9-49). Cambridge University Press.

Tri., W. H., \& Sofian, I. (2010). Indonesia Climate Change Sectoral Roadmap: Scientific Basis, Badan Perencanaan Pembangunan Nasional (Bappenas). Indonesia.

\section{Copyrights}

Copyright for this articleis retained by the author(s), with first publication rights granted to the journal.

This is an open-access article distributed under the terms and conditions of the CreativeCommons Attribution license (http://creativecommons.org/licenses/by/3.0/). 